\title{
DIAKRONIKA
}

Vol. 19 No. 2 Th. 2019 p: $133-148$

ISSN: 1411-1764 (Print) | 2620-9446 (Online)

http://diakronika.ppj.unp.ac.id

\section{Literasi Sejarah Sebagai Upaya Penanaman Karakter Bagi Anak}

\author{
Hera Hastuti, Zafri, Iqrima Basri \\ herahastuti@fis.unp.ac.id \\ Universitas Negeri Padang
}

\begin{abstract}
Education is the main way to advance a nation. Progress is not only in terms of technological or physical aspects but also progress in human behavior and civilization. So it is not strange that the character of the people of a nation is a reflection of the quality of education. At present, the problem of the character of Indonesia's young generation is crucial to be overcome. The decline in character does not only occur in children with minimal education, but also occurs in children with secondary schooling. Many cases are related to this character decline, for example in Nagari Sungai Nyalo, Pesisir Selatan Regency. Nagari Sungai Nyalo as an active area in tourism, but not accompanied by changes in the behavior of its generation for the better, is evident that there are still many children of Nagari Sungai Nyalo who extort extortion to tourists, besides the spoken language has not been used reflecting the values of politeness. Facing this problem several attempts were made, one of which was the inculcation of character values through historical literacy. The essence of history is a storehouse of values and characters, one of which can be obtained through the story of historical figures, such as; Buya Hamka, Mohammad Hatta, Agus Salim, Natsir, Tan Malaka and other historical figures. These figures are great figures who not only have intellectual intelligence but also have extraordinary character and character. The moral values and personalities of these figures need to be instilled in the younger generation of children, as the authors have done with the children of Nagari Sungai Nyalo in Pesisir Selatan Regency.
\end{abstract}

Keywords: Character Learning, Literacy, Historical Figures, Moral Values, PolitenessValues.

\begin{abstract}
Abstrak
Pendidikan merupakan jalan utama untuk memajukan suatu bangsa. Kemajuan tidak hanya dari aspek teknologi ataupun fisiknya saja tetapi juga kemajuan dalam tingkah laku dan peradaban manusianya. Maka tidaklah aneh bahwa karakter masyarakat suatu bangsa menjadi cerminan dari kualitas pendidikannya. Hari ini, persoalan karakter generasi muda Indonesia menjadi hal yang sangat krusial untuk dibenahi. Kemerosotan karakter tidak hanya terjadi dikalangan anak-anak yang minim pendidikan, namun juga terjadi pada anak-anak yang bersekolah tinggi. Banyak kasus yang berhubungan dengan kemerosotan karakter ini, sebagai contoh yang terjadi di Nagari Sungai Nyalo, Kabupaten Pesisir Selatan. Sungai Nyalo sebagai daerah yang sedang bergiat dengan pariwisata, namun tidak dibarengi
\end{abstract}


dengan perubahan tingkah laku generasinya menjadi lebih baik, terbukti masih banyak anak-anak Sungai Nyalo yang melakukan Pungli (Pungutan Liar) pada wisatawan, selain itu tutur bahasa yang digunakan dalam kesaharian juga belum mencerminkan nilai-nilai kesopanan. Menghadapi persoalan tersebut beberapa upaya yang dilakukan, salah satunya adalah penanaman nilai karakter melalui literasi sejarah. Hakikatnya sejarah adalah gudang nilai dan karakter, salah satunya bisa didapat melalui kisah tokoh-tokoh sejarah, seperti; Buya Hamka, Mohammad Hatta, Agus Salim, Natsir, Tan Malaka dan tokoh sejarah lainnya. Tokoh-tokoh tersebut adalah tokoh hebat yang tidak hanya cerdas secara intelektual tetapi juga memiliki akhlak dan karakter yang luar biasa. Nilai moral dan kepribadian tokohtokoh tersebut perlu ditanamkan kepada anak-anak generasi muda, seperti halnya yang telah penulis lakukan pada anak-anak Sungai Nyalo Kabupaten Pesisir Selatan.

Kata Kunci: Pembelajaran Karakter, Literasi, Tokoh Sejarah, Nilai Moral, Nilai Kesopanan. 4.0 International License.

\section{Pendahuluan}

Bicara tentang literasi, tentunya tidak lepas dari bicara tentang buku. Bahkan ketika diadakan survei tentang kemampuan literasi masyarakat suatu negara yang jadi poin utama yang dipakai sebagai alat ukurnya adalah seberapa banyak jumlah buku yang dibaca tiap harinya. Hal ini tidaklah mengherankan, karena buku dianggap sebagai sumber wawasan dan ilmu pengetahuan. Sejalan dengan pendapat Paul Hazard (dalam Permatasari, Inten, \& Mulyani, 2017) dengan dikenalkannya buku sejak awal pada anakanak ibarat mereka diberikan sayap untuk terbang setinggi-tinginya. Mereka akan melihat dunia dengan pandangan yang luas. Wawasan mereka menjadi berkembang dan banyak hal baru yang bisa mereka ketahui. Membiasakan anak bersentuhan dengan buku akan mempermudah mereka untuk mencintai buku dan mengembangkan literasinya (Anindyarini, Sumarwati, Waluyo, Hastuti, \& Mujiyanto, 2019).Tentu saja ini menegaskan hubungan kuat antara buku, literasi, dan ilmu pengetahuan.

UESCO juga menambahkan bahwa literasi merupakan hak setiap orang dan merupakan dasar untuk belajar sepanjang hayat. Pernyataan tersebut mengindikasikan bahwa literasi menjadi salah satu point penting bagi setiap orang dalam menjalankan kehidupan yang sejatinya adalah belajar sepanjang hayat. Hasil survei yang dilakukan oleh Central Connecticut State University (CCSU) tahun 2016, menyatakan bahwa peringkat literasi Indonesia berada diurutan 60 dari 61 negara, tepat berada satu tingkat di atas Botswana 
(Damarjati, 2019). Hal ini tentu saja sangat memprihatinkan, mengingat kemampuan literasi merupakan salah satu tonggak kemajuan dan peradaban suatu bangsa.

Tidak ada yang memungkiri literasi merupakan hal sangat penting dalam kehidupan, karena lewat membaca kita akan semakin banyak tahu, dan dengan banyak mengetahui maka kita akan semakin banyak berubah ke arah yang lebih baik. Hal ini juga berlaku dalam upaya menghadapi permasalahan urgent mengenai 'dekadensi moral' atau sederhananya adalah permasalahan karakter di Indonesia. Literasi bukanlah sebuah disiplin ilmu yang kaku dan memiliki lingkup tertentu, melainkan kemampuan yang bisa dan 'seharusnya' ada disetiap chapter kehidupan.

Hakikatnya literasi selalu memberikan manfaat yang sangat besar bagi kehidupan, terutama dibidang pendidikan. Pengetahuan yang menunjang tumbuhnya nilai karakter sangat dibutuhkan dewasa ini. Fakta ini menyadarkan semua pihak untuk bekerja sama menggiatkan gerakan literasi di satuan pendidikan, tempat tinggal, dan komunitas dalam upaya penguatan pendidikan karakter. Kementerian Pendidikan dan Kebudayaan (Kemdikbud) memperkuat gerakan literasi sekolah dengan meluncurkan Gerakan Literasi Nasional pada peringatan Hari Sumpah Pemuda, 28 Oktober 2017 (Kemendikbud, 2015).

Salah satu bagian dari literasi adalah literasi sejarah. Literasi sejarah mampu menanamkan nilai karakter atau nilai-nilai luhur yang mampu dipetik dan dipedomani dari peristiwa sejarah dan tokoh sejarah. Terkait dengan hal tersebut, Perkumpulan Keluarga Peduli Pendidikan (KERLIP) juga mulai menggiatkan literasi sejarah bangsa dengan merintis Komunitas Literasi Sejarah Bangsa (KOLASE) pada 10 Juli 2015 bersama mitra dalam Gerakan Indonesia Pintar. Hal ini dilakukan sebagai upaya dalam membentuk karakter bangsa yang berlandaskan kepada sejarah Indonesia sendiri (Sriyulianti, 2017).

Permasalahan terkait merosotnya karakter anak bangsa sudah menjadi isu yang tidak asing lagi, karena persoalan ini sudah menjadi national problem dan semakin marak terjadi akhir-akhir ini. Hal ini bisa dibuktikan dari banyaknya anak bangsa yang terjerat kasus 'etika', bahkan rata-rata terjadi dikalangan anak bangsa yang 'berpendidikan tinggi'. Salah satu kasus terbaru yang terjadi beberapa pekan lalu, yaitu kasus anggota DPR dari fraksi PDIP, Arteria Dahlan. Persoalan tersebut terjadi ketika ia diundang sebagai pembicara dalam acara Mata Najwa yang membahas Perppu KPK, pada hari kamis, 10 Oktober 2019 lalu. Selama acara berlangsung, Arteria kerap tampil menggebu-gebu bahkan cenderung emosional terhadap lawan bicara. Dia sempat terlibat adu mulut dengan beberapa narasumber. Hal yang sangat 
mengecewakan adalah ketika ia beberapa kali mendebat seorang ahli ekonomi yang juga guru besar ekonomi, yakni Professor Dr. Emil Salim yang jelas sudah berusia jauh diatasnya. Bahkan Arteria Dahlan sempat melontarkan kata-kata yang tidak sepantasnya, seperti mengatakan Prof. Dr. Emil Salim sebagai professor 'sesat' dan 'bangsat' (Ningrum, 2019).

Dari beberapa kasus diatas bisa kita nilai bahwa pendidikan di Indonesia masih belum sepenuhnya berhasil melahirkan insan cendikia yang berintelektual dan berkarakter baik. Indonesia kelebihan orang-orang pintar, tapi masih sangat sedikit yang mampu menyelaraskan otak dengan akhlaknya. Salah satunya seperti kasus yang penulis paparkan di atas.

Masih berkaitan dengan permasalahan etika, hal yang sama dengan kasus berbeda juga kerap terjadi dikalangan anak-anak Sungai Nyalo, Kabupaten Pesisir Selatan. Kehidupan lingkungan pesisir yang umumnya lebih keras mempengaruhi hampir $70 \%$ watak dan karakter anak-anak disana. Menjadi daerah wisata yang sering dikunjungi wisatawan lokal maupun internasional hendaknya menjadikan lingkungan Sungai Nyalo ramah terhadap pengunjung, namun yang terjadi justru malah sebaliknya. Banyaknya kasus Pungli (Pungutan Liar) yang rata-rata dilakukan oleh anak-anak remaja usia sekolah membuat pengunjung merasa kurang nyaman. Hal ini juga dialami oleh tim PKM UNP 2019 yang berkunjung kesana untuk urusan pengabdian. Tidak hanya itu, tak jarang pengunjung harus terlibat komunikasi yang kurang baik serta pelayanan yang kurang ramah dari remaja dan anak-anak Sungai Nyalo. Bahkan gaya bahasa yang masih kasar dan cenderung menyalahi nilai kesopanan kerap terlontar dari mulut mereka tak terkecuali pada pengunjung yang jauh lebih tua usianya. Cerita di atas bukan hanya sebatas isapan jempol belaka, karena itu diangkat berdasarkan kenyataan dan pengalaman Tim.

Dua kasus yang penulis paparkan diatas bukan dimaksudkan untuk menjudge kalangan tertentu, melainkan untuk menunjukan bahwa karakter memang sudah menjadi hal yang 'asing' bagi sebagian rakyat Indonesia. Terlepas dari seberapa tinggi jenjang sekolah yang diduduki, tidak menjamin apakah karakter baik itu tumbuh dikalangan manusia yang berpendidikan tinggi atau malah dikalangan anak yang tidak bersekolah sekalipun. Urgensi dari kegiatan ini adalah untuk menelaah literasi di kalangan anak-anak dan masyarakat di Nagari Sungai Nyalo sekaligus untuk mencarikan solusi untuk permasalahan literasi yang sangat urgent di daerah pesisir.

Menanggapi permasalahan tersebut, merupakan tanggung jawab kita bersama untuk kembali menanamkan nilai-nilai karakter kepada generasi 
selanjutnya, agar kelak tumbuh sebagai insan yang memiliki intelektual tinggi serta berkarakter baik sebagaimana yang di cita-citakan, tidak 'mengekor' kepada generasi sebelumnya, hingga kasus-kasus serupa tidak akan terjadi lagi dimasa yang akan datang. Untuk itu karakter perlu ditanamkan kepada anak sejak usia dini, salah satu caranya ialah melalui literasi sejarah.

\section{Metode Penelitian}

Penelitian ini merupakan penelitian lapangan, dengan menggunakan metode deskriptif. Layaknya sebuah penelitian deskriptif, penelitian ini mendeskripsikan langkah-langkah kegiatan yang dilaksanakan agar memberi dampak secara langsung pada subjek penelitian. Penelitian dilakukan pada anak-anak Nagari Sungai Nyalo dengan jumlah sekitar 70 orang anak. Adapun langkah-langkah yang dilaksanakan dalam penelitian ini yaitu;

a. Motivasi Literasi

Kegiatan pertama yang dilakukan adalah memberikan motivasi tentang literasi, tim menyampaikan hal-hal menarik terkait literasi dan hal-hal positif lainnya yang memotivasi anak-anak Sungai Nyalo.

b. Pemaparan Keteladanan Tokoh Sejarah

Kemudian, tim memberikan motivasi literasi dalam bentuk literasi tokoh. Kegiatan ini dilakukan untuk menanamkan nilai karakter yang ada pada tokoh kepada anak-anak Sungai Nyalo. Dalam kegiatan ini ada antusiasme luar biasa dari anak-anak Sungai Nyalo dalam mendengarkan kisah-kisah hebat yang penuh keteladanan dari Buya Hamka, Bung Hatta, Kiyai Agus Salim, dan tokoh bangsa lainnya seperti Mohammad Natsir, Tan Malaka, dll.

c. Pembagian kelompok

Selanjutnya tim membagi anak-anak Sungai Nyalo kedalam beberapa kelompok dan setiap kelompok memiliki satu pelatih atau pemandu. Kegiatan yang dilakukan adalah anak-anak di ajak menulis dan kemudian membacakan tulisannya tersebut didepan semua teman-temannya.

d. Penilaian

Kemudian hasil tulisan anak-anak Sungai Nyalo tersebut diberi nilai dan peringkat oleh tim, penilaian ini dilakukan untuk memacu semangat menulis anak-anak Sungai Nyalo.

e. Reward

Terakhir tim memberikan reward kepada anak- anak yang memiliki tulisan yang bagus dan menngikuti kegiatan secara optimal. 


\section{Pembahasan}

National Institute for Literacy, mendefinisikan Literasi sebagai "kemampuan individu untuk membaca, menulis, berbicara, menghitung dan memecahkan masalah pada tingkat keahlian yang diperlukan dalam pekerjaan, keluarga dan masyarakat." Definisi ini memaknai Literasi dari perspektif yang lebih kontekstual. Dari definisi ini terkandung makna bahwa definisi Literasi tergantung pada keterampilan yang dibutuhkan dalam lingkungan tertentu (Edc, 2017).

Literasi tidak memiliki definisi secara baku, karena konsep literasi merupakan produk global, bukan bersifat nasional maupun lokal. Namun, terlepas dari keambiguan tersebut, literasi merupakan pengetahuan yang dibutuhkan dan harus dimiliki oleh setiap orang salah satunya adalah untuk mengikuti zeitgeist yang akan terus berkembang setiap waktu, maka hidup juga butuh pembaharuan (Keefe \& Copeland, 2011).

Sebagaimana yang telah disampaikan pada pendahuluan, bahwa literasi bukanlah satu disiplin yang kaku dan memiliki lingkup yang tertentu, literasi ada dalam semua chapter kehidupan. Salah satu bentuk literasi adalah literasi sejarah. Sederhananya, literasi sejarah adalah pengetahuan mengenai sejarah yang didapatkan melalui membaca, menulis maupun melaui kegiatan yang berkenaan dengan 'aksara' lainnya.

Hakikatnya sejarah adalah disiplin yang memiliki segudang nilai-nilai luhur yang dapat dipetik dari setiap peristiwanya. Hal ini menjadikan literasi penting dan merupakan indikator yang semestinya diutamakan dalam menciptakan kehidupan yang lebih baik. Explicit-nya lagi, literasi sejarah perlu dilakukan untuk menanamkan nilai karakter kepada manusia, baik karakter tersebut didapatkan dari makna peristiwa, maupun teladan kepribadian tokoh yang memberikan impact positif bagi kualitas diri manusia.Literasi merupakan hal yang penting, karena berkenaan dengan 'melek huruf', dan tentu saja hal ini sangat berkaitan erat dengan disiplin ilmu sejarah yang sejatinya dibangun dengan kegiatan menulis dan membaca (Wineburg \& Reisman, 2015).

Kata character berasal dari bahasa Yunani charassein, yang berarti to engrave (melukis, menggambar), seperti orang yang melukis kertas, memahat batu atau metal. Berakar dari pengertian yang seperti itu, character kemudian diartikan sebagai tanda atau ciri yang khusus, sehingga melahirkan suatu pandangan bahwa karakter adalah 'pola perilaku yang bersifat individual, keadaan moral seseorang'. Setelah melewati tahap anak-anak, seseorang 
memiliki karakter, cara yang dapat diramalkan bahwa karakter seseorang berkaitan dengan perilaku yang ada di sekitar dirinya (Ryan, Bohlin, \& McDonnell, 1999).

Istilah karakter banyak digunakan dalam kehidupan manusia. Pada konteks penerbitan surat kabar, karakter berhubungan dengan huruf dalam kalimat, dalam bidang seni film, karakter dihubungkan dengan peran pemain. Sedangkan bila dikaitkan dengan masalah jiwa manusia (inner self) karakter merupakan bagian yang sangat penting dalam sosok manusia. Tidak adanya karakter yang melekat pada diri manusia, maka manusia telah kehilangan jati dirinya sebagai makhluk yang sangat mulia. Pernyataan ini secara tidak langsung menjelaskan bahwa karakter adalah bagian paling berharga dari seorang manusia. Encyclopedia of Pcychology, mendifinisikan character as the habitual mode of bringing into harmony the task presented by internal demands and by the external word, it is necessarly a fungtion of the constant, organized, and integrating part of the personality which is called ego (Corsini \& Ozaki, 1994).

Karakter menuntun watak seseorang dalam bertindak, berkeinginan, dan bersikap, sehingga seseorang tersebut dikenal sebagai manusia baik atau justru sebaliknya oleh khalayak umum (Park, Peterson, \& Seligman, 2004). Karakter yang baik berkaitan dengan mengetahui yang baik (knowing the good), mencintai yang baik (loving the good), dan melakukan yang baik (acting the good). Ketiga ideal ini satu sama lain sangat berkaitan. Seseorang lahir dalam keadaan bodoh, dorongan-dorongan primitif yang ada dalam dirinya kemungkinan dapat memerintahkan atau menguasai akal sehatnya. Maka, efek yang mengiringi pola pengasuhan dan pendidikan seseorang akan dapat mengarahkan kecenderungan, perasaan, dan nafsu besar menjadi beriringan secara harmoni atas bimbingan akal dan juga ajaran agama. Mengetahui yang baik berarti dapat memahami dan membedakan antara yang baik dan yang buruk. Mengetahui yang baik berarti mengembangkan kemampuan untuk menyimpulkan atau meringkaskan suatu keadaan, sengaja, memilih sesuatu yang baik untuk dilakukan, dan kemudian melakukannya.

Filosof kontemporer seperti Michael Novak, mendifinisikan karakter sebagai campuran atau perpaduan dari semua kebaikan yang berasal dari tradisi keagamaan, cerita, dan pendapat orang bijak, yang sampai kepada kita melalui sejarah. Menurut Novak, tak seorang pun yang memiliki semua kebajikan itu, karena setiap orang memiliki kelemahan-kelemahan. Seseorang dengan karakter terpuji dapat dibedakan dari yang lainnya (Lickona, 1991). Sehingga dapat dipahami bahwa karakter adalah sifat, watak, tabiat, budi pekerti atau akhlak yang dimiliki seseorang yang merupakan ciri khas yang dapat membedakan perilaku, tindakan dan perbuatan antara yang satu 
dengan yang lain. Jadi, meskipun karakter berada direlung paling dalam sisi batin manusia namun dapat terlihat atau terdeteksi, karena ia ditampilkan oleh seseorang lewat perilakunya sehari-hari.

Penanaman karakter bagi anak-anak dan remaja Nagari Sungai Nyalo melalui literasi sejarah salah satunya dilakukan dengan memaparkan bagaimana keteladan tokoh sejarah bangsa seperti Buya Hamka, Haji Agus Salim, Mohammad Hatta, Mohammad Natsir, dan Tan Malaka. Pemilihan tokoh sejarah yang kesemuanya berasal dari Minangkabau bukanlah tanpa alasan, agar anak-anak dan remaja Nagari Sungai Nyalo mengetahui bahwa orang-orang hebat yang mendunia tersebut berasal dari kampung halamannya sendiri, Sumatera Barat.

Haji Abdul Malik Karim Amrullah atau lebih dikenal dengan julukan 'Hamka' adalah seorang ulama, sastrawan, sejarawan, dan juga politikus yang sangat terkenal di Indonesia. Buya hamka juga seorang pembelajar yang otodidak dalam bidang ilmu pengetahuan seperti filsafat, sastra, sejarah, sosiologi dan politik, baik Islam maupun Barat. Hamka pernah menjabat sebagai Menteri Agama dan juga aktif dalam perpolitikan Indonesia. Hamka lahir di desa kampung Molek, Maninjau, Sumatera Barat, 17 Februari 1908 dan meninggal di Jakarta, 24 Juli 1981 pada umur 73 tahun.

Meskipun beliau sudah wafat kurang lebih 38 tahun lalu, namun kepribadiannya tercatat dalam sejarah sebagai bekal yang bisa dijadikan teladan hingga saat ini. Tutur lembut kata dan sikap tegas beliau dalam memberikan nasehat kepada anak-anaknya kembali dituangkan dalam sebuah karya dari salah seorang putra beliau, yakni Irfan Hamka dalam buku yang berjudul 'Ayah.' Tulisan yang dirangkai apa adanya, yang diangkat dari catatan harian Irfan Hamka dalam setiap peristiwa yang dialami bersama ayahnya (Irfan, 2013). Membaca buku 'Ayah' berhasil membuat pembaca hanyut dalam setiap helainya, dan merasakan keuletan pribadi beliau yang sangat sulit ditemukan di zaman modern ini. Inilah salah satu contoh dari literasi sejarah, dengan membaca sejarah Hamka, kembali mengingatkan kita bahwa karakter baik itu bisa ditanamkan lewat teladan tokoh sejarah bangsa yang mampu menyelaraskan otak dan juga akhlak.

Banyak hal yang dapat diteladani dari sosok Hamka, salah satunya, bagaimana Hamka begitu santun dalam mengajari anaknya, bahkan meminta izin dahulu kepada anaknya untuk ia beri nasehat. Seperti yang ditulis oleh Irfan Hamka, salah satu scene yang paling menyentuh adalah ketika Irfan Hamka mengatakan bapaknya tidak pernah memarahinya secara kasar, 
bahkan untuk menasehati anak-anaknya, Hamka meminta izin terlebih dahulu, "...nak, bapak ingin menasehatimu, maukah engkau mendengarkannya?"

Belum lagi kesabaran beliau dalam menghadapi fitnah, sebut saja dari Pramodya Ananta Toer, Soekarno, bahkan M. Yamin. Ketiga orang ini pada akhirnya mengakui 'kebesaran hati' seorang Hamka. Pram, saat mau menikahkan anaknya dengan pemuda yang berbeda agama, ia menyuruh calon menantunya belajar Islam pada Hamka. Lalu apa reaksi Hamka, ia dengan senang hati mengajari anak dan calon menantu Pram tentang Islam, bahkan Hamka jua lah yang mengislamkan calon menantu Pram secara langsung. Padahal semua orang tau bagaimana sebelumnya tulisan-tulisan Pram dalam media massa dan koran yang mengolok-olok dan memfitnah Hamka.

Lebih parah dari Pram, Soekarno malah menjebloskan Hamka dalam penjara tanpa peradilan, dengan tuduhan bahwa Hamka akan melakukan makar terhadapnya. Namun, apa yang terjadi setelah Soekarno lengser dari kekuasaannya, dipengasingannya ia meminta ketika ia meninggal ia disholatkan oleh Hamka. Hamka dengan kelapangan hati, memenuhi permintaan terakhir Soekarno, bahkan ia yang mengimami dan ikut mengantar Soekarno ke peristirahatan terakhirnya.

Lalu, bagaimana dengan M. Yamin, ia yang selalu mencemooh Hamka sebagai Buya yang tak paham agama, bahkan selalu menentang pernyataan Hamka secara terang-terangan dengan kata-kata kasar. Tidak sedikitpun Hamka membalasnya, bahkan hanya tersenyum saja. Akan tetapi diakhir hayatnya Yamin menyadari sendiri kesalahan-kesalahannya, ia memohon pada Hamka untuk menjadi imam sholat jenazahnya kelak, tidak hanya itu, Yamin juga meminta Hamka ikut mengantarkan pulang jenazahnya ke kampung halaman, Sawah Lunto. Lagi-lagi, dengan keiklhasan hati Hamka menuruti keinginan oarang-orang yang telah mendzoliminya. Sebuah keteladanan karakter yang luar biasa, yang tidak lagi ditemukan pada zaman ini.

Pemilik nama lengkap Dr.(H.C.) Drs. H. Mohammad Hatta atau lebih dikenal sebagai Bung Hatta, lahir di Bukittinggi, Sumatera Barat, 12 Agustus 1902 dan meninggal di Jakarta, 14 Maret 1980 pada umur 77 tahun. Hatta merupakan seorang pejuang, negarawan, tokoh proklamator, dan juga Wakil Presiden Indonesia yang pertama (Alfarizi, 2009).

Hatta lahir dari keluarga ulama Minangkabau, Sumatera Barat. la menempuh pendidikan dasar di Sekolah Melayu, Bukittinggi, dan pada tahun 1913-1916 melanjutkan studinya ke Europeesche Lagere School (ELS) di Padang. 
Saat usia 13 tahun, sebenarnya ia telah lulus ujian masuk ke HBS (setingkat SMA) di Batavia (Jakarta), namun ibunya menginginkan Hatta agar tetap di Padang, mengingat usianya yang masih muda. Akhirnya Bung Hatta melanjutkan studi ke MULO di Padang. Baru pada tahun 1919 ia pergi ke Batavia untuk studi di Sekolah Tinggi Dagang Prins Hendrik School. Hatta menyelesaikan studinya dengan hasil sangat baik, dan pada tahun 1921, Bung Hatta pergi ke Rotterdam, Belanda untuk belajar ilmu perdagangan/bisnis di Nederland Handelshogeschool Di Belanda, ia kemudian tinggal selama 11 tahun. Pada tangal 27 November 1956, Bung Hatta memperoleh gelar kehormatan akademis yaitu Doctor Honoris Causa dalam Ilmu Hukum dari Universitas Gadjah Mada di Yogyakarta. Pidato pengukuhannya berjudul “Lampau dan Datang” (Noer, 1990).

Berbicara tentang Hatta, pasti slalu mengarah pada kepribadiannya yang ulet dan identik dengan kata 'bijak' juga 'cerdas'. kecintaannya pada buku berhasil menjadikan Hatta sebagai tokoh pembaca sekaligus pemikir yang ulung. Background keluarga yang berasal dari Minang, sehingga ia terbiasa tumbuh dengan aturan-aturan falsafah adat dan budaya yang kental, hal tersebut jugalah yang menjadi dasar Hatta bisa menjadi seorang tokoh sejarah bangsa yang memiliki intelektual dan karakter yang luar biasa.

Sejarah mencatat Hatta sebagai tokoh sejarah bangsa dengan segala kisah teladan dan inspiratifnya, tertuang dalam berbagai karya tulis. Salah satunya adalah buku Cara Baik Bung Hatta, karya Prof.Mestika Zed. Buku ini secara detail menjelaskan betapa 'elok' nya pribadi seorang Hatta. Harum namanya tidak hanya semerbak di masa lampau, namun mewangi hingga masa kini dan masa yang akan datang. Karakternya yang tenang mengindikasikan kepribadian seorang pemikir ulung yang selalu memiliki ide terbaik dalam menyelesaikan suatu masalah. Hal tersebut telah dibuktikan oleh Hatta dalam perjuangannya meraih kemerdekaan Indonesia (Hutabarat, Harsasto, \& Utomo, 2015).

Dari sekian banyak nilai karakter yang dapat diteladani dari seorang Hatta, beberapa diantaranya yaitu; religius, jujur, sabar, santun, tidak memakan hal yang bukan haknya, dan pecinta ilmu. Gajinya sebagai wakil presiden selalu habis digunakan untuk membeli buku. Dia juga tidak pernah mengambil uang yang ia yakini bukan haknya. Hatta pernah menyuruh asistennya mengembalikan dana taktis Wakil Presiden sebesar Rp 25 ribu (jika dikalkulasikan dengan nilai rupiah sekarang jadi sekitar 300-an juta rupiah). Padahal jika tidak dikembalikan pun tidak apa-apa. Dana taktis itu tidak perlu 
dipertanggungjawabkan. Tapi Hatta orang jujur yang punya kehormatan, sehingga ia merasa uang itu bukanlah haknya.

Hatta terkenal sebagai pecinta ilmu sehingga sangat menghargai bukubukunya. Kecintaannya kepada buku terpancar jelas dari raut wajahnya yang tenang, lewat membaca Hatta melahirkan ide-ide dan pemikiran yang luar biasa hebat bagi kepentingan negara dan bangsa. Bahkan, dalam satu kisah, ketika Hatta dipenjarakan, ia tidak memberontak, asalkan dia diizinkan membawa buku-bukunya. Hatta percaya, sekalipun raganya dipenjara, dengan buku ia merasa bebas. Perpustakaan pribadi Bung Hatta memiliki lebih dari 8.000 buku, dominasi buku Sejarah, filsafat, Budaya, Politik, Agama, Bahasa dan lain-lain. Hal inilah yang turut menyumbang kemampuan Beliau dalam berdiplomasi untuk memperjuangkan Kemerdekaan Republik Indonesia, baik semasa di negeri Belanda maupun di Tanah Air.

Hatta Semasa hidupnya juga dikenal sebagai sosok yang religius, mengamalkan ajaran-ajaran islam selaku seorang muslim. Kepribadiannya yang santun tercerminkan dari setiap gerak dan tindakannya. Jujur dan juga sabar, bahkan ketika ia menjadi pejabat, tidak sedikitpun melunturkan karakternya. Meskipun telah mengenyam pendidikan Eropa, dan bergaul banyak dengan orang-orang hebat dari berbagi penjuru dunia, tidak membuat ia kehilangan jati dirinya sebagai seorang yang bersahaja. Alkisah diceritakan, bahwa Hatta pernah menyimpan sobekan majalah yang memuat gambar sepatu kulit bermerk Belli. Rupanya Hatta begitu menginginkan sepatu tersebut, namun sayang hingga akhir hayatnya, gajinya sebagai wakil presiden tidak pernah cukup untuk membeli sepatu tersebut. Sebenarnya sangat mudah bagi Hatta menggunakan kekuasaannya untuk kepentingan diri sendiri, tapi Hatta bukanlah orang yang seperti itu. la memegang teguh nilainilai luhur dalam hidupnya. Pernah juga waktu kecil, Hatta kecil dihukum oleh ayahnya berdiri dibawah pohon di belakang rumahnya, karena tidak ikut Sholat Subuh berjamaah di Surau (Masjid). Hingga saat menjelang Magrib ayah Hatta baru ingat (kesibukannya sebagai seorang ulama) bahwa ia telah menghukum Hatta. Ayah Hatta kemudian mencari Hatta, dan didapati Hatta masih berdiri dibawah pohon tersebut. Keteguhan hati Hatta dalam menepati janji meski dalam bentuk hukuman, kejujurannya dalam bersikap, seolah tanpa tanding jika menilik bagimana karakter generasi bangsa hari ini.

Salah seorang cendekiawan yang juga lahir dan berdarah Minang adalah Mashudul Haq yang kemudian terkenal dengan nama Haji Agus Salim. Lahir pada tanggal 8 Oktober 1884 di Koto Gadang Bukittinggi. Keluarganya merupakan kalangan keluarga pegawai pemerintah, terutama ayah dan kakaknya. Ayahnya, Sutan Mohammad Salim, meskipun seorang bumiputera, telah memangku jabatan yang cukup tinggi, yakni sebagai Jaksa Kepala di 
Riau. Sementara ibunya, Siti Zaenah, merupakan keluarga yang terpandang di Koto Gadang. Menempati Status Sosial yang tinggi, membuka jalan bagi Agus Salim untuk mengikuti pendidikan sekolah seluas-luasnya.

Pergantian nama dari Mashudul Haq menjadi Agus Salim mengandung riwayat yang menunjukkan keteguhan watak tersendiri seorang Agus Salim. Nama Agus Salim berasal dari pengasuhnya yang berasal dari suku Jawa yang selalu memanggil anak asuhannya dengan sebutan "Gus" yang berarti anak yang bagus. Ternyata nama panggilan itu menjadi populer di sekolahnya. Sedangkan Salim berasal dari nama ayahnya. Pada waktu itu penonjolan nama menurut garis keturunan ayah (dianjurkan dalam Islam) belum lazim dan bertentangan dengan adat. Di Minangkabau masih berlaku hukum garis keturunan melalui garis ibu, karenanya penggunaan sebutan dari pihak ayah merupakan bukti keteguhan hati dan keberaniannya menentang arus adat. Hal ini bukanlah persoalan yang gampang, sebab kesemuanya itu memerlukan tindakan yang ulet, sabar dan berani (Insan \& Nurmayanti, 2019).

Semenjak kecil Agus Salim gemar sekali membaca buku terutama yang berisi pengetahuan. Agaknya dia menyadari, bahwa pengetahuan yang diperoleh di bangku sekolah saja tidak cukup karena itu perlulah diperluas dengan banyak membaca. Dikarunia otak yang cemerlang Agus Salim mampu belajar berbagai macam hal secara otodidak. Salah satu keistimewaannya yaitu kemampuannya mengerti dan mempergunakan berbagai bahasa Asing. Tak kurang dari sepuluh bahasa yang ia kuasai.

Tiap kali kita mendengar nama $H$. Agus Salim, biasanya dua hal yang langsung mencuat dalam benak kita: kepiawaiannya sebagai diplomat dan ulama besar yang pada masa hidupnya sudah terkenal sampai ke luar negeri, terutama di dunia Islam. Akan tetapi bila disigi lebih jauh, di balik akal budinya yang lincah dan tajam itu, Salim sesungguhnya adalah manusia ensiklopedis yang pernah dianugrahkan Tuhan untuk bangsa Indonesia abad ke-20. Menurut Hamka manusia seperti Haji Agus Salim jarang dilahirkan ke dunia. Dalam masa 100 tahun paling banyak manusia seperti ini dilahirkan hanya satu orang di Indonesia. Dia menguasai hampir seluruh bidang ilmu. Dalam dirinya, tubuhnya yang kecil itu, tersimpan energi yang menyinari kepribadiannya sebagai pemimpin yang berkarakter kuat dan dalam ilmunya. la tak hanya dikenal sebagai ahli agama Islam dan politikus ulung, tetapi juga dikenal sebagai filosof, ahli sejarah, ahli astronomi, pemikir dan sekaligus praktisi pendidikan dan menguasai banyak bahasa asing. Dengan pelbagai 
macam keahlian ini, kedudukannya sebagai salah seorang tokoh "bapak bangsa" (the founding fathers) menjadi lebih unik dan memiliki banyak kelebihan yang tak mungkin dijangkau oleh para pemimpin pada generasinya, bahkan juga tidak oleh bapak pendiri bangsa yang lainnya, apa lagi manusia biasa (Zed, 2004).

Setelah proklamasi 17 Agustus 1945 Indonesia hanya diakui Belanda secara de facto atas Jawa dan Sumatera, sedang pengakauan de jure internasional para pemimpin Republik masih harus berjuang keras. Itu artinya mereka harus memasuki wilayah diplomatik yang sama sekali asing dalam pengalaman para bapak bangsa. Salim menemukan dirinya pada kedudukan yang tepat ketika ia secara berturut-turut dipercaya menduduki pos Kementerian Luar Negeri pada masa perjuangan kemerdekaan. Mula-mula sebagai Menteri Muda Luar Negeri dan akhirnya Menteri Luar Negeri penuh dalam Kabinet Amir Sjarifuddin (1947-1948) dan Kabinet Hatta (1948-1950).

Salah satu misi diplomatik yang strategis waktu itu ialah melakukan kunjungan diplomatik ke Timur Tengah. Kisah-kisah perjalanan diplomatik Salim ke Timur Tengah telah banyak diceritakan. Misalnya bagaimana Salim tampil sebagai lobbyst yang ulung dengan mengandalkan kamahirannya dalam berbahasa Arab, tetapi sewaktu-waktu ia dengan mudah juga bisa berganti ke bahasa Eropa lainnya. Ketajaman dan kelincahannya dalam membaca apa yang tersebunyi dalam kepala orang lain, ditambah dengan humornya yang penuh sindiran, menimbulkan efek kekaguman dan kehangatan dalam cara dia menarik simpati pejabat negara, politisi dan wartawan dalam forum-forum pertemuan dan media massa Timur Tengah.

Selain sebagai Bapak Bangsa, Agus Salim juga merupakan seorang ayah yang baik, ia mendidik putra-putrinya secara langsung, sehingga putra putri Agus Salim tidak bersekolah seperti anak pada umumnya. Dalam mendidik, Agus Salim menerapkan asas pendidikan bahwa mendidik pada dasarnya mendidik diri sendiri (Opvoeding is zelf opvoeding). Pendidik harus jujur tidak boleh bohong, untuk menjaga agar anak-anak tetap percaya kepadanya. Setiap hari dibalik kesibukannya yang luar biasa untuk Bangsa, Agus Salim selalu menyempatkan diri mendidik putra-putranya. Haji Agus Salim pandai memikat hati putra-putranya, tidak henti-hentinya ia menerangkan atau menjawab pertanyaan-pertanyaan sebelum putra-putranya puas dan mengerti. Mereka bebas menyanggah keterangan ayahnya dan dengan sabar ditunjukkan mana yang benar dan mana yang salah. Di dalam persoalan membaca buku putra-putranya bebas memilih, selama mereka berani membaca buku-buku itu di samping ibunya yang sedang menjahit maka tidak ada sesuatu larangan. Tumbuhlah perasaan aman dan tidak ada rahasia di antara mereka. Terhadap putra-putranya ditekankan bahwa mereka tidak 
hanya harus membaca buku-buku saja, tetapi harus diusahakan mempelajari sampai mengerti isinya.

\section{Simpulan}

Dari tulisan ini kita mengetahui bahwa persoalan yang paling urgent yang tengah dihadapi oleh bangsa indonesia ialah persoalan karakter. Mulai menurunnya karakter anak-anak bangsa terlihat dari cara berprilaku anakanak dalam sehari-hari. Menghadapi permasalahan karakter di kalangan anakanak bangsa Indonesia ini, banyak jalan yang bisa ditempuh, salah satunya adalah melalui literasi sejarah, tepatnya dengan menceritakan kisah-kisah tokoh besar sejarah bangsa yang memiliki kepribadian luhur dan juga cerdas secara akademik. Penanaman karakter melalui sejarah kepribadian tokoh ini sudah penulis terapkan pada anak-anak di Nagari Sungai Nyalo, Kabupaten Pesisir Selatan. Kegiatan literasi sejarah ini berhasil menarik minat anak-anak Sungai Nyalo untuk belajar, membaca, dan mengetahui tentang kepribadian tokoh sejarah bangsa, sehingga tujuan untuk menanamkan karakter kepada anak-anak mulai terlaksana secara bertahap.

Di zaman yang semakin canggih dan maju ini, orang menyebutnya dengan era revolusi 4.0, teknologi seolah semakin menggeser peran manusia sebagai makhluk sosial. Nilai karakter yang semstinya semakin meningkat beriringan dengan perkembangan zaman yang semakin serba modern, namun kenyataan yang harus dihadapi justru sebaliknya, karakter anak bangsa Indonesia malah semakin menurun. Bukankah satu hal yang janggal ketika bangsa yang diraih dengan penuh perjuangan, dan besar menjadi negara yang berideologikan Pancasila, namun manusianya justru sebagian besar masih jauh dari nilai dan norma yang ada. Indonesia hendaknya mampu menciptakan kehidupan yang sesuai dengan dasar negara.

Salah satu cara yang bisa dilakukan untuk mengembalikan bangsa Indonesia kepada pancasila ialah melalui literasi. Melalui literasi, kita bisa menanamkan nilai-nilai luhur, nilai-nilai perjuangan bangsa untuk menjadikan Indonesia sebagai negara yang berdaulat, serta menanamkan nilai karakter kepada generasi penerus bangsa. Karena sejatinya kemerosotan karakter dapat terjadi ketika generasi bangsa sudah mulai 'alergi' dengan buku, dan sudah mulai menjauh dari kegiatan membaca. Untuk itu, hal ini butuh penanganan khusus dari berbagai pihak, agar kelak Indonesia mampu melahirkan generasi penerus, insan cendikia yang berilmu dan juga berkarakter baik. 


\section{Daftar Rujukan}

Alfarizi, S. (2009). Mohammad Hatta: biografi singkat, 1902-1980. Yogyakarta: Garasi.

Anindyarini, A., Sumarwati, S., Waluyo, B., Hastuti, S., \& Mujiyanto, Y. (2019). STRATEGI MENGHIDUPKAN BUDAYA LITERASI MELALUI DONGENG. SENADIMAS.

Corsini, R. J., \& Ozaki, B. D. (1994). Encyclopedia of psychology (Vol. 1). New York: Wiley New York.

Damarjati, D. (2019). Benarkah Minat Baca Orang Indonesia Serendah Ini?, Sabtu 05 Januari 2019. Diakses pada 18 Desember 2019. Detiknews. Retrieved from https://news.detik.com/berita/d-4371993/benarkahminat-baca-orang-indonesia-serendah-ini

Edc. (2017). What is Literacy? Education Development Center. Retrieved from https://www.edc.org/newsroom/articles/what literacy.

Hutabarat, P. N., Harsasto, P., \& Utomo, S. (2015). Pemikiran Politik Mohammad Hatta Tentang Demokrasi. Journal of Politic and Government Studies, 4(2), 146-160.

Insan, W., \& Nurmayanti, N. (2019). Diplomat dari Negeri Kata-Kata ( Politik Diplomasi Haji Agus Salim pada Inter Asian RelationConference dan Komisi Tiga Negara ). HISTORIA: Jurnal Pendidik Dan Peneliti Sejarah, I/(2), 111-124. Retrieved from https://ejournal.upi.edu/index.php/historia/article/viewFile/16625/9465.

Irfan, H. (2013). Ayah. Jakarta: Republika Penerbit.

Keefe, E. B., \& Copeland, S. R. (2011). Research \& practice for persons with severe disabilities. University of New Mexico, 36(3-4), 92-99.

Kemendikbud. (2015). Garakan Literasi Sekolah. Retrieved from https://www.kemdikbud.go.id/main/blog/2015/08/mendikbudluncurkan-gerakan-literasi-sekolah-4514-4514-4514

Lickona, T. (1991). An integrated approach to character development in the elementary school classroom. Moral, Character, and Civic Education, 6783.

Ningrum, D. A. (2019). Mengintip Harta Kekayaan Arteria Dahlan, Anggota DPR Sebut Emil Salim Profesor Sesat. Merdeka.Com. Retrieved from https://www.merdeka.com/uang/mengintip-harta-kekayaan-arteriadahlan-anggota-dpr-sebut-emil-salim-profesor-sesat.html

Noer, D. (1990). Mohammad Hatta: biografi politik. Jakarta: Lembaga Penelitian, Pendidikan dan Penerangan Ekonomi dan Sosial.

Park, N., Peterson, C., \& Seligman, M. E. P. (2004). Strengths of character and well-being. Journal of Social and Clinical Psychology, 23(5), 603-619.

Permatasari, A. N., Inten, D. N., \& Mulyani, D. (2017). Literasi Dini Dengan Teknik Bercerita. FamilyEdu, 3(1), 20-28.

Ryan, K., Bohlin, K. E., \& McDonnell, S. N. (1999). Building character in schools: Practical ways to bring moral instruction to life. San Francisco: Jossey-Bass San Francisco.

Sriyulianti, Y. (2017). Keluarga Peduli Pendidikan (KERLIP) Menggiatkan 
ISSN: 1411-1764 (Print) | 2620-9446 (Online)

Literasi Sejarah Bangsa dengan Merintis Komunitas Literasi Sejarah Bangsa (KOLASE). Beritasatu.

Wineburg, S., \& Reisman, A. (2015). Disciplinary literacy in history: A toolkit for digital citizenship. Journal of Adolescent \& Adult Literacy, 58(8), 636-639.

Zed, M. (2004). Haji Agus Salim The Founding Father dari Negeri Kata-kata. Jakarta. 